\title{
Use of agro-industrial residues for lipase production by Candida viswanathii in a solid-state cultivation system
}

\author{
Utilização de resíduos agroindustriais para a produção de lipase por Candida viswanathii em \\ sistema de cultivo em estado sólido \\ A. C. M. Lima*; C. M. Santos; I. L. Santos; L. T. A. Bastos; A. C. Santos; F. C. \\ Paula-Elias; A. F. Almeida \\ Programa de Pós-Graduação em Ciências e Tecnologia de Alimentos, Laboratório de Microbiologia Aplicada, \\ Universidade Federal do Tocantins, 77001-090, Palmas-TO, Brasil \\ *alannacristinne@hotmail.com \\ (Trabalho avaliado e selecionado pela Comissão do III CTOCTA)
}

\begin{abstract}
Lipases are an important group of enzymes that catalyze the hydrolysis of triacylglycerol and there are many industrial applications. The aim of this work was to produce the lipase by the yeast Candida viswanathii using solid state culture with agro-industrial wastes (barley bagasse, corn husk, corncob, soybean seed coat and soybean husk). The biomass pretreatment methods were evaluated, as well as the media supplementation with nitrogen and mixing substrates. Also, the efficiency of olive oil and poultry fat was evaluated on the induction of lipase production, followed by the scale-up from $20 \mathrm{~g}$ to $100 \mathrm{~g}$. The enzyme activities in the cultures without pretreatement were higher when soybean seed coat supplemented with both olive oil $(7.06 \mathrm{U} / \mathrm{gss})$ and poultry fat $(8.40 \mathrm{U} / \mathrm{gss})$ were used. However, the pretreated substrates did not demonstrate a satisfying induction of lipolytic activity. From the nitrogen sources, yeast extract showed an increase of approximately twice the original production with both olive oil (18.12 U/gss) and poultry fat (15.98 U/gss) supplementation. On the scale-up step, the results demonstrated that, for the $20 \mathrm{~g}$ culture, the best lipase production was observed on the $7^{\text {th }}$ day $(33.52 \mathrm{U} / \mathrm{gss})$, while for the $100 \mathrm{~g}$ culture the highest lipase activity was after 5 days (17.88 U/gss). The cultivation of ground soybean skin without pretreatment supplemented with yeast extract as a source of nitrogen, with fresh barley bagasse and poultry fat was the best combination.
\end{abstract}

Keyword: supplementation, scaling up, poultry fat.

Lipases são um grupo importante de enzimas catalisadoras da hidrólise de triacilglicerol e possuem diversas aplicações industriais. Com o objetivo de produzir a enzima lipase, utilizou-se a levedura Candida viswanathii por meio de cultivos em substratos sólidos empregando resíduos agroindustriais (bagaço de cevada, palha de milho, sabugo de milho, tegumento de soja e casca de soja). Foram avaliados prétratamentos da biomassa, a suplementação do meio de cultivo com fontes de nitrogênio e com mistura de substratos. Também foram avaliados a eficiência de azeite de oliva e gordura de frango na indução da produção de lipase e posterior escalonamento de $20 \mathrm{~g}$ para $100 \mathrm{~g}$. As atividades enzimáticas dos cultivos sem pré-tratamento foram maiores utilizando tegumento de soja suplementado tanto com azeite de oliva (7,06 U/gss) quanto com gordura de frango $(8,40 \mathrm{U} / \mathrm{gss})$. Porém os substratos pré-tratados não foram propícios para indução da atividade lipolítica. A adição de extrato de levedura aumentou a produção em aproximadamente 2 vezes, tanto suplementando-se com azeite de oliva (18,12 U/gss) quanto com gordura de frango (15,98 U/gss). No escalonamento, no cultivo de $20 \mathrm{~g}$ a melhor produção de lipase foi após 7 dias de cultivo (33,52 U/gss), já no cultivo com $100 \mathrm{~g}$ a máxima atividade de lipase foi obtida no quinto dia $(17,88 \mathrm{U} / \mathrm{gss})$. O cultivo de tegumento de soja moído sem pré-tratamento suplementado com extrato de levedura como fonte de nitrogênio, com bagaço de cevada in natura e gordura de frango foi a melhor combinação.

Palavras-chave: suplementação, escalonamento, gordura de frango.

\section{INTRODUCTION}

Biotechnology is one of the most extraordinary technological tools today. Its applications have contributed to the structuring of new economic and social models. Among the various applications of biotechnology, some enzymes act directly in the fermentation processes to obtainment a range of products [1]. 
Enzymes are proteins produced by all living organisms, acting as a catalyst for numerous biochemical reactions. In addition to being in vivo catalysts, enzymes can also be in vitro catalysts for various reactions, especially in the industry [2]. Lipases (triacylglycerol hydrolases, E.C. 3.1.1.3), are an important group of catalyst enzymes and have diverse applications in the food, detergent, and pharmaceutical industries [3].

In Brazil, agricultural waste is produced in large quantities, but its main use has been limited to animal feed or simply sent to landfills. However, agricultural residues are ideal for use in biotechnological processes, mainly due to their low cost, accessibility, and nutritional compositions, as they contain carbon, nitrogen, and minerals. These have been used in biotechnological processes to produce compounds with high added value [4-6]. In addition, it has been a practice to perform pre-treatments on substrates before producing the enzyme, to make the lignocellulosic complex nutrients more accessible to the microorganism, thus favoring its growth [7-9].

To use these residues as a whole, solid-state fermentation or cultivation is a tool to be used. This process refers to the cultivation of microorganisms on or within particles in a solid matrix, where the liquid content is at a water level that ensures cell growth and metabolism but does not exceed the maximum binding capacity of water with the matrix solid. It is also possible to add nutrient solutions to the substrate for better adaptation of the microorganism to the nutritional conditions of the medium [10-12].

As part of the industrial production cost of enzymes is due to the fermentation medium [1315], the present work had as objective the production of lipase by Candida viswanathii through cultivation in solid substrates using agro-industrial residues.

\section{MATERIALS AND METHODS}

\subsection{Substrates and lineage maintenance}

Corn husk and corn cob were provided by Pamonharia da Dona Júlia, Gurupi-TO. The barley bagasse was provided by Cervejaria Serra Beer, Porangatu-GO and the soybean husk and soybean tegument were provided by Fazendão, Gurupi-TO. Rice husk was offered by Beneficiadora Gargetins, Gurupi-TO. The olive oil used in the crops was from the Galo brand and the poultry fat was provided by Frigorífico Fricok, Rio Claro-SP. The other reagents used were of analytical grade.

Candida viswanathii strain is being maintained at the Laboratory of Biotechnology, Analysis of Food and Product Purification (LABAP), Federal University of Tocantins, Campus de GurupiTO. The strain is maintained by the method of Castelani (1967) [16] at $4{ }^{\circ} \mathrm{C}$ and periodic cultures were carried out in dextrose potato agar medium at $30^{\circ} \mathrm{C}$, for 3 days.

\subsection{Solid-state cultivation}

\subsubsection{Pretreatments of lignocellulosic biomass}

The substrates corn husk, corn cob, soybean husk, soybean husk, barley bagasse were previously subjected to a thermal and chemical pre-treatment using sulfuric acid. The substrates were ground (particles between $1 \mathrm{~mm}-2 \mathrm{~mm}$ ) in a knife mill. One part has undergone pretreatment and another part has not been treated. Heat treatment was performed with superheated steam for $15 \mathrm{~min}$ at $121^{\circ} \mathrm{C}$. Subsequently, the acid treatment was carried out with a solution of sulfuric acid $\left(\mathrm{H}_{2} \mathrm{SO}_{4}\right) 1.09 \%$ with a $1: 5$ ratio $(\mathrm{w} / \mathrm{v})$ for a period of $27 \mathrm{~min}$ at $121{ }^{\circ} \mathrm{C}$. After treatment, vacuum filtration and successive washings were carried out until the $\mathrm{pH}$ stabilized. 


\subsubsection{Preparation of the inoculum}

Candida viswanathii strain was previously cultivated in potato dextrose agar medium in a slanted tube for three days at $30{ }^{\circ} \mathrm{C}$. The pre-inoculum was prepared in Erlenmeyer flasks $(125$ $\mathrm{mL})$ containing $50 \mathrm{~mL}$ of modified Vogel liquid medium [17] supplemented with $1.5 \%(\mathrm{~m} / \mathrm{v})$ of olive oil and $0.2 \%(\mathrm{~m} / \mathrm{v})$ of yeast extract, $\mathrm{pH} 6.0$ and sterilized at $121{ }^{\circ} \mathrm{C}$, for $15 \mathrm{~min}$. The inoculation of the culture medium was carried out with $1 \mathrm{~mL}$ of a cell suspension $\left(10^{7}\right.$ cells $\left./ \mathrm{mL}\right)$ removed from the tube in $0.85 \%$ saline solution $(\mathrm{NaCl})$ and kept under agitation at $210 \mathrm{rpm}$, at 28 ${ }^{\circ} \mathrm{C}$ for 24 hours [10]. Five milliliters of this pre-inoculum were inoculated into substrates used for solid substrate cultivation.

\subsubsection{Preparation of solid substrates}

The solid-state cultivation were prepared in Erlenmeyer flasks $(250 \mathrm{~mL})$ containing $10 \mathrm{~g}$ of each substrate ground in nature or pre-treated: corn straw, corn cob, barley bagasse, soybean husk, and soybean husk. The substrates were added with $10 \mathrm{~mL}$ of a Vogel salt solution [17] without nitrogen to provide an initial moisture content of 50\%. Cultivations were supplemented with olive oil or poultry fat $(40 \%, \mathrm{~m} / \mathrm{v})$ to induce lipase production. Culture flasks were sterilized at $121{ }^{\circ} \mathrm{C}$ for $20 \mathrm{~min}$. Then, they were inoculated with the pre-inoculum and incubated at $30^{\circ} \mathrm{C}$ for 5 days. Cultivations were carried out in duplicate.

\subsection{Enzyme extraction and determination of enzyme activity}

After cultivation, to proceed with the extraction of the enzyme, ice-cold distilled water was added and kept under orbital agitation of $140 \mathrm{rpm}$, at $28^{\circ} \mathrm{C}$ for $60 \mathrm{~min}$. For the cultivation of 10 $\mathrm{g}, 20 \mathrm{~g}$, and $100 \mathrm{~g}, 100 \mathrm{ml}, 200 \mathrm{ml}$, and $1000 \mathrm{ml}$ of water were added, respectively. Subsequently, vacuum filtration was performed in an ice bath, with 3 to 4 layers of gauze, to promote the separation of solids, and the supernatant was centrifuged at $9000 \mathrm{rpm}, 4{ }^{\circ} \mathrm{C}$ for $20 \mathrm{~min}$. The supernatant resulting from the centrifugation was used to determine the lipase activity.

Lipase activity was determined with p-nitrophenyl palmitate (pNPP) as a substrate. pNPP was solubilized in $0.5 \mathrm{ml}$ dimethylsulfoxide (DMSO) and then diluted to $0.5 \mathrm{mM}$ with McIlvaine $\mathrm{pH}$ 4.0 buffer containing $0.5 \%$ Triton X-100. In test tubes, $900 \mu \mathrm{l}$ of reaction medium were added and the hydrolysis of pNPP was determined discontinuously at $40{ }^{\circ} \mathrm{C}$ by the release of $\mathrm{p}$ nitrophenol. After pre-incubation of the substrate in a water bath for 5 minutes, the reaction was started by adding $0.1 \mathrm{~mL}$ of the properly diluted sample. The reaction was stopped at different intervals with thermal shock $\left(90^{\circ} \mathrm{C}, 1 \mathrm{~min}\right)$, followed by the addition of $1 \mathrm{~mL}$ of saturated sodium tetraborate solution. Absorbance reading was performed at $410 \mathrm{~nm}$. Controls were prepared without the addition of enzymes [18]. A unit of enzyme activity was defined as the amount of enzyme that releases $1 \mu \mathrm{mol}$ of $\mathrm{pNP}$ per min per $\mathrm{mL}$.

The enzymatic activity was determined through the relationship between absorbance (Abs), molar absorptivity coefficient $(\varepsilon)$, used volume of protein extract $\left(\mathrm{V}_{\mathrm{i}}\right)$, final reaction volume $\left(\mathrm{V}_{\mathrm{f}}\right)$, reaction time ( $\mathrm{t}$ ), and dilution factor (d), given by Equation (1).

$$
A=\frac{A b s}{\varepsilon} \cdot \frac{1}{V_{i}} \cdot 10^{3} \cdot V_{f} \cdot \frac{1}{t} \cdot d
$$

\subsection{Supplementation with nitrogen sources}

Crops with ground soybean tegument were supplemented with the addition of different nitrogen sources at a concentration of $5 \%(\mathrm{~m} / \mathrm{m})$ [19]: casein, ammonium chloride, yeast extract, and urea. 


\subsection{Supplementation within natura substrates}

The ground soybean seed coat substrate was supplemented with other substrates in nature 1:1 $(\mathrm{m} / \mathrm{m})$ : rice husk, soybean seed coat, and barley bagasse to promote less compaction and better use of the substrate. Yeast extract was added to the cultures as a source of nitrogen, at a concentration of $5 \%(\mathrm{~m} / \mathrm{m})$ and inoculated with $8 \mathrm{~mL}$ of pre-inoculum. Cultivation was carried out in duplicate.

\subsection{Scaling up}

The ground soybean tegument substrate was supplemented with fresh barley bagasse and was cultivated in two scales, $20 \mathrm{~g}$, and $100 \mathrm{~g}$, using the ratio $1: 1(\mathrm{~m} / \mathrm{m})$. Yeast extract $(5 \%)$, poultry fat $(40 \%)$ and pre-inoculum in the proportion $2: 1(\mathrm{w} / \mathrm{v})$ were added to the cultivation, in addition to Vogel in the proportion 1:1 (w/v). The cultures were kept at $30 \mathrm{oC}$ and samples were collected at intervals of 3, 5, and 7 days. The $20 \mathrm{~g}$ cultivation was carried out in Erlenmeyer flasks and the $100 \mathrm{~g}$ was carried out in autoclavable polypropylene bags $(20 \mathrm{~cm} \times 25 \times 0.06)$.

To extract the enzyme from the $100 \mathrm{~g}$ culture, $1000 \mathrm{~mL}$ of ice-cold distilled water was added to the culture in a beaker, after homogenization with a glass stick, the volume was divided into $250 \mathrm{~mL}$ Erlenmeyer flasks and the same conditions were used. from previous extractions.

\section{RESULTS AND DISCUSSION}

\subsection{Selection of lignocellulosic substrates for lipase production}

In this first stage, the productive capacity of Candida viswanathii to secrete lipase in different lignocellulosic substrates, which received physicochemical pre-treatments and supplements, was evaluated (Table 1).

Table 1: Lipase production using different agro-industrial residues as substrate.

\begin{tabular}{ccccc}
\hline \multirow{2}{*}{ Substrate } & \multicolumn{2}{c}{ No Pretreatement (U/gss) } & \multicolumn{2}{c}{ With Pretreatment (U/gss) } \\
\cline { 2 - 5 } & Olive Oil & Poultry Fat & Olive Oil & Poultry Fat \\
\hline Barley bagasse & 2.16 & 2.47 & 2.07 & 1.66 \\
Corn Straw & 1.54 & 1.40 & 097 & 1.32 \\
Corn cob & 4.07 & 1.44 & 0.49 & 0.37 \\
Soybean Integument & 7.06 & 8.40 & 095 & 1.18 \\
Soybean hulls & - & - & 1.42 & 0.82 \\
\hline
\end{tabular}

$*$ Cultures were carried out for 120 hours at $30^{\circ} \mathrm{C}$. The inoculum was prepared in submerged fermentation for 24 hours at $28{ }^{\circ} \mathrm{C}$. The substrates were supplemented with $10 \mathrm{~mL}$ of Vogel salts solution without nitrogen source and $40 \%$ of olive oil or poultry fat.

The enzymatic activities of the crops without pretreatment were higher using soybean tegument as substrate, reaching 7.06 and $8.40 \mathrm{U} / g s s$ when supplemented with olive oil and poultry fat, respectively. With barley bagasse and corn husk, the lowest levels of production were obtained, using olive oil or poultry fat as a supplement. The differences observed in production levels among agro-industrial residues may be related to the different chemical compositions of biomass, which in turn influence the growth and accessibility of substrates by microorganisms and, as a result, the secretion of enzymes. [20, 21].

Subsequently, the yeast was cultivated on substrates that underwent physicochemical pretreatment and even supplementing with olive oil or poultry fat, there was no induction in the production of lipase when compared to lignocellulosic material without pretreatment. The lipolytic activity in this composition was maximum using barley bagasse supplemented with olive 
oil (2.07 U/gss). A decrease in activity was noted when the substrates corn straw, soybean coat, and soybean husk were used and supplemented with olive oil or poultry fat. Corn on the cob was shown to be inefficient for lipase production supplemented with both olive oil and poultry fat.

Although the goals of pretreatment are to make the lignocellulosic complex nutrients more accessible to microorganisms [22, 23], depending on operating conditions, hemicellulosic sugars solubilized as a result of pretreatment can follow reaction pathways that lead to degradation products, such as furfural, hydroxymethylfurfural (HMF), and various organic acids that derive from lignin degradation, and have been described as potential inhibitors of microorganism growth. This is probably why the pretreated substrates were not efficient for lipase production $[21,24]$.

From the different substrates evaluated, the soybean tegument was selected for the next step, due to its ability to induce the production of the lipase enzyme, in addition to being easy to obtain and its low cost.

\subsection{Supplementation with nitrogen sources}

Some nitrogen sources were analyzed in the production of lipase by $C$. viswanathii. The results suggest that among the nitrogen sources, yeast extract increased production by approximately 2fold, both supplemented with olive oil $(18.124 \mathrm{U} / \mathrm{gss})$ and with poultry fat $(15.998 \mathrm{U} / \mathrm{gss})$ (Table 2). Inorganic nitrogen sources such as ammonium chloride ( $\mathrm{NH} 4 \mathrm{Cl})$ caused a decrease in lipase production when compared to the substrate without supplementation.

Table 2: Lipase production using soybean tegument supplemented with a nitrogen source.

\begin{tabular}{ccc}
\hline \multirow{2}{*}{ Nitrogen source } & \multicolumn{2}{c}{ Lipase activity (U/gss) } \\
\cline { 2 - 3 } & Olive oil & Poultry fat \\
\cline { 2 - 3 } Casein & 5.62 & 6.38 \\
Yeast extract & 18.12 & 15.98 \\
Ammonium chloride & 1.08 & 0.26 \\
Urea & 7.81 & 10.66 \\
\hline
\end{tabular}

*Cultures were carried out for 120 hours at $30^{\circ} \mathrm{C}$. The inoculum was prepared in submerged fermentation for 24 hours at $28{ }^{\circ} \mathrm{C}$. The substrates were supplemented with $10 \mathrm{~mL}$ of Vogel salts solution without nitrogen source and $40 \%$ of olive oil or poultry fat.

Almeida et al. (2016) [19] observed that supplementing wheat bran with 5\% (w/w) yeast extract resulted in a 3.8-fold increase in lipase production when compared to cultivation without the addition of the source. of nitrogen. Moftah et al. (2012) [21] used cake from the manufacture of olive oil to produce lipase using Candida utilis supplemented with $3 \%(\mathrm{~m} / \mathrm{m})$ of yeast extract and achieved an activity of $25.0 \mathrm{U} / \mathrm{gss}$ and by combining the production with alkaline treatment achieved a 39\% increase. The author also suggests that the increase in lipase production when using nitrogen sources in cultivation is probably based on the presence of some specific bioactive peptides that act as inducers of lipase production.

Thus, yeast extract was selected for supplementation with other substrates and subsequent scaling.

\subsection{Supplementation with in natura substrates}

The use of solid substrate can affect the microorganism's accessibility due to porosity and particle sizes of the substrate, as it hinders the extent and rate of microbial colonization, air penetration, $\mathrm{CO}_{2}$ removal, and enzyme extraction [25]. The size of the substrate particle should provide greater spacing between them, facilitating gas exchange and, consequently, microbial growth. Exceedingly small particles agglomerate and impair aeration, resulting in low enzyme production $[26,27]$. To reduce compaction, the cultivation was supplemented with other natural substrates, such as rice husk, soybean seed coat, and barley bagasse. 
The cultivation of $C$. viswanathii in-ground soybean tegument combined with fresh barley bagasse, supplemented with poultry fat increased the level of lipase production from 15.98 to $20.04 \mathrm{U} / \mathrm{gss}$ (Tables 2 and 3). The opposite occurred with the presence of olive oil in which the lipase production decreased by $7.00 \mathrm{U} / \mathrm{gss}$.

Poultry fat is a by-product of poultry slaughter and contains high contents of the fatty acids palmitic, oleic, and linoleic [28, 29]. Oleic acid is indicated as an inducer of lipase production due to the stimulation of microbial metabolism and the lipase biosynthesis pathway [30].

Table 3: Lipase production using soybean tegument supplemented within natural substrates.

\begin{tabular}{ccc}
\hline \multirow{2}{*}{ Substrates } & \multicolumn{2}{c}{ Lipase activity (U/gss) } \\
\cline { 2 - 3 } Rice husk & Olive oil & Poultry fat \\
\cline { 2 - 3 } Soy Integument & 9.68 & 11.50 \\
Barley bagasse & 4.18 & 8.73 \\
& 11.06 & 20.04 \\
\hline
\end{tabular}

$*$ Cultures were carried out for 120 hours at $30{ }^{\circ} \mathrm{C}$. The inoculum was prepared in submerged fermentation for 24 hours at $28{ }^{\circ} \mathrm{C}$. The substrates were supplemented with $20 \mathrm{~mL}$ of Vogel salts solution without nitrogen source and $40 \%$ of olive oil or poultry fat.

Regarding the use of barley bagasse, the polysaccharide and protein content make it particularly susceptible to microbial growth and degradation. Thus, the use of this readily available, low-cost residue as a substrate for enzyme production can be one of the ways to substantially reduce the cost of enzyme production [31]. Thus, the mixture of soybean tegument with barley bagasse supplemented with poultry fat was selected for scaling.

\subsection{Scaling up}

To scale up, two types of cultures were carried out: one containing $20 \mathrm{~g}$ of solid substrate and another containing $100 \mathrm{~g}$ of solid substrate, and the lipase activity was evaluated at times 3,5 , and 7 days (Table 4). The results showed that in the $20 \mathrm{~g}$ culture the best lipase production was observed on the seventh day (33.52), while in the $100 \mathrm{~g}$ culture the maximum lipase activity was obtained on the fifth day (17.88). On the third day of $100 \mathrm{~g}$ culture, there was a decrease in lipase production, probably due to the difficulty of growing the biomass in a solid medium, as the increase in lipase activity is associated with cell growth [32].

The seventh day of $100 \mathrm{~g}$ culture was not efficient, possibly due to nutrient limitation that decreased microbial growth [33], thus disfavoring lipase activity. Therefore, the scaling to $100 \mathrm{~g}$ did not obtain good results regarding the cultivation in $20 \mathrm{~g}$ of substrate.

Table 4: Scaling of lipase production using soybean tegument supplemented with barley bagasse and poultry fat at different times (days).

\begin{tabular}{ccc}
\hline & $\mathbf{2 0} \mathbf{g}$ & $\mathbf{1 0 0 g}$ \\
Time (days) & Lipase Activity (U/gss) & Lipase Activity (U/gss) \\
\hline 3 & 17.17 & 1.55 \\
5 & 32.37 & 17.88 \\
7 & 33.52 & 7.59 \\
\hline
\end{tabular}

In solid-state cultivation, oxygen transfer and the complexity of temperature and water content control are limiting factors $[34,35]$. The substrates used in solid cultivation have low thermal conductivities, consequently, they increase the heat accumulation inside the bioreactor. Therefore, heat removal is a fundamental step in several studies [36, 37]. With the use of larger size particles, heat removal can be achieved with forced air circulation, through larger particles that have more space between them [34]. 


\section{CONCLUSION}

The solid-state cultivation of $C$. viswanathii using different agro-industrial residues, aiming to increase the scale of lipase production, allows us to conclude that the cultivation of ground soybean tegument without pretreatment supplemented with yeast extract as a nitrogen source, with barley bagasse in nature to provide aeration and poultry fat was the best combination.

There are still points to be explored regarding the production of the lipase enzyme, such as improving the technique of cultivation and extraction of the enzyme and improving the heat exchange in the medium. In addition, it is valid to perform a characterization of the enzyme in question for further escalation.

\section{REFERENCES}

1. Brasil. Ministério da Agricultura, Pecuária e Abastecimento. Boletim Técnico de Biotecnologia Agropecuária. Brasília (DF): MAPA/EMBRAPA; 2010.

2. Jegannathan KR, Nielsen PH. Environmental assessment of enzyme use in industrial production e a literature review. J Clean Prod. 2013;42:228-40. doi: 10.1016/j.jclepro.2012.11.005

3. Hasan F, Shah AA, Hameed A. Methods for detection and characterization of lipases: A comprehensive review. Biotechnol Adv. 2009 Jun;27(6):782-798, doi:10.1016/j.biotechadv.2009.06.001

4. Salihu A, Alam MZ, Karim MIA, Salleh HM. Lipase production: An insight in the utilization of renewable agricultural residues. Resour Conserv Recycl. 2012 Jan;58:36-44. doi: 10.1016/j.resconrec.2011.10.007

5. Leite P, Sousa D, Fernandes H, Ferreira M, Costa AR, Filipe D, et al. Recent advances in production of lignocellulolytic enzymes by solid-state fermentation of agro-industrial wastes. Curr Opin Green Sustain Chem. 2021 Feb;27:100407. doi: 10.1016/j.cogsc.2020.100407

6. Sadh PK, Duhan S, Duhan JS. Agro-industrial wastes and their utilization using solid state fermentation: a review. Bioresour Bioprocess. 2018 Jan;5:1. doi: 10.1186/s40643-017-0187-z

7. Soccol CR, Costa ESF, Letti LAJ, Karp SG, Woiciechowski AL, Vandenberghe LP. Recent developments and innovations in solid state fermentation. Biotechnol Res Innov. 2017 Jan;1(1):52-71. doi: 10.1016/j.biori.2017.01.002

8. Farinas CS. Developments in solid-state fermentation for the production of biomass-degrading enzymes for the bioenergy sector. Renew Sustain Energy Rev. 2015 Dec;52:179-88. doi: 10.1016/j.rser.2015.07.092

9. Kumar A, Kanwar SS. Lipase production in Solid-State Fermentation (SSF): Recent developments and biotechnological applications. Dyn Biochem Process Biotechnol Mol Biol. 2012 Feb;6(1):13-27.

10. Bianchi VLD, Moraes IO, Capalbo DMF. Fermentação em estado sólido. In: Schmidell N, Lima UA, Aquarone E, Borzani W, editors. Biotecnologia Industrial. Volume 2: Engenharia Bioquímica. São Paulo: Edgard Blucher; 2001. p. 247-276.

11. Santos CR, Almeida SS, Cavalcanti EDAC, Freire DMG, Moura-Nunes N, Monteiro M, et al. Enzymes produced by solid state fermentation of agro-industrial by-products release ferulic acid in bioprocessed whole-wheat breads. Food Res Int. 2021 Feb;140:109843. doi: 10.1016/j.foodres.2020.109843

12. Rosales E, Pazos M, Sanromán MA. Solid-state fermentation for food applications. In: Pandey A, Larroche C, Soccol CR, editors. Current developments in biotechnology and bioengineering: Current advances in solid-state fermentation. The Netherlands: Elsevier; 2018. p. 319-55. doi: 10.1016/B978-0444-63990-5.00015-3

13. Salihu A, Alam MZ, Abdulkarim MI, Salleh HM. Optimization of lipase production by Candida cylindracea in palm oil mill efluent based medium using statistical experimental design. J Mol Catal B Enzym. 2011, Apr;69(1-2):66-73. doi: 10.1016/j.molcatb.2010.12.012

14. Teles AS, Chávez DW, Oliveira RA, Bon EP, Terzi SC, Souza EF, et al. Use of grape pomace for the production of hydrolytic enzymes by solid-state fermentation and recovery of its bioactive compounds. Food Res Int. 2019 Jun;120:441-8. doi: 10.1016/j.foodres.2018.10.083

15. Idris ASO, Pandey A, Rao SS, Sukumaran RK. Cellulase production through solid-state tray fermentation, and its use for bioethanol from sorghum stover. Bioresour Technol. 2017 Oct;242:26571. doi: 10.1016/j.biortech.2017.03.092

16. Castellani A. Long term maintenance and cultivation of the common pathogenic fungi of man in sterile distilled water. Pontif Acad Sci (Commentarii) 1968;2(17):1-8.

17. Vogel HJA. Convenient growth medium for Neurospora crassa (medium N). Microb Genet Bull. 1956;13:42-3. 
18. Almeida AF, Tauk-Tornisielo SM, Carmona EC. Acid lipase from Candida viswanathii: Production, biochemical properties, and potential application. BioMed Res Int. 2013 Oct;2013:435818. doi: $10.1155 / 2013 / 435818$

19. De Almeida AF, Dias KB, Da Silva ACC, Terrasan CRF, Tauktornisielo AM, Carmona EC. Agroindustrial wastes as alternative for lipase production by Candida viswanathii under solid-state cultivation: Purification, biochemical properties, and its potential for poultry fat hydrolysis. Enzyme Res. 2016 Sep;2016:1353497. doi: 10.1155/2016/1353497

20. Cara C, Ruiz E, Oliva JM, Sáez F, Castro E. Conversion of olive tree biomass into fermentable sugars by dilute acid pretreatment and enzymatic saccharification. Biores Technol. 2008 Apr;99(6):1869-76. doi: 10.1016/j.biortech.2007.03.037

21. Moftah OAS, Grbavčić S, Žuža M, Luković N, Bezbradica D, Knežević-Jugović Z. Adding value to the oil cake as a waste from oil processing industry: Production of lipase and protease by Candida utilis in solid state fermentation. Appl Biochem Biotechnol. 2012 Jan;166:348-64. doi: 10.1007/s12010-0119429-2

22. Kumar A, Kanwar SS. Lipase production in Solid-State Fermentation (SSF): Recent developments and biotechnological applications. Dyn Biochem Process Biotechnol Mol Biol. 2012 Feb;6:13-27. doi: 10.4172/2155-9821.1000203

23. Kim D. Physico-chemical conversion of lignocellulose: inhibitor effects and detoxification strategies: A mini review. Molecules. 2018 Feb;23(2):309. doi: 10.3390/molecules23020309

24. Jönsson LJ, Martín C. Pretreatment of lignocellulose: formation of inhibitory by-products and strategies for minimizing their effects. Bioresour Technol. 2016 Jan;199:103-12. doi: 10.1016/j.biortech.2015.10.009

25. Manpreet, S, Sawraj S, Sachin D, Pankaj S, Banerjee UC. Influence of process parameters on the production of metabolites in solid-state fermentation. Malalaysian J Microbiol. 2005;1(2):1-9. doi: 10.21161/MJM.120501

26. Castro RJS, Nishide TG, Sato HH. Production and biochemical properties of proteases secreted by Aspergillus niger under solid state fermentation in response to diferente agroindustrial substrates. Biocatal Agric Biotechnol. 2014;3(4):236-45. doi: 10.1016/j.bcab.2014.06.001

27. Pandey A, Soccol CR, Rodriguez-Leon JA, Nigam P. Solid-state fermentation in biotechnology: Fundamentals and applications. New Delhi (IN): Asiatech Publishers; 2001.

28. Chiu MC, Gioielli LA, Grimaldi R. Lipídios estruturados obtidos a partir da mistura de gordura de frango, sua estearina e triacilgliceróis de cadeia média. I- Composição em ácidos graxos e em triacilgliceróis. Rev. Quím Nova. 2008;31(2):232-7. doi: 10.1590/S0100-40422008000200008

29. Oliveira BH, Santos RÉ, Loiola LE, Nascimento VM. Overproduction and properties of lipase by a wild strain of Burkholderia lata LBBIO-BL02 using chicken fat. Ann Microbiol. 2015;65(2):865-77. doi: 10.1007/s13213-014-0928-6

30. Zarevúcka M. Olive oil - constituents, quality, health properties and bioconversions. Rijeka (HR): InTech Europe; 2012.

31. Aliyu S, Bala M. Brewer's spent grain: A review of its potentials and applications. African J Biotechnol. 2011 Aug;10(3):324-31. doi: 10.5897/ajbx10.006

32. Edwinolive NG, Thirunavukarasu K, Naidu RB, Gowthaman MK, Kambe TN, Kamini NR. Scale up of a novel tri-substrate fermentation for enhanced production of Aspergillus niger lipase for tallow hydrolysis. Bioresource Technol. 2010 Sep;101:6791-6. doi: 10.1016/j.biortech.2010.03.091

33. Decesaro A, Rigon MR, Thomé A, Colla LM. Produção de biossurfactantes por microrganismos isolados de solo contaminado com óleo diesel. Quím Nova. 2013;36(7):947-54. doi: 10.1590/S010040422013000700005

34. Bhargav S, Panda BP, Ali M, Javed S. Solid-state fermentation: An overview. Chem Biochem Eng Q. 2008;22(1):49-70.

35. Yazid NA, Barrena R, Komilis D, Sanches A. Solid-state fermentation as a novel paradigm for organic waste valorization: A review. Sustainability. 2017 Feb;9(2):1-28. doi: 10.3390/su9020224

36. Geoffry K, Achur RN. Screening and production of lipase from fungal organisms. Biocatal Agric Biotechnol. 2018 Apr;14:241-53. doi: 10.1016/j.bcab.2018.03.009

37. Sadh PK, Kumar S, Chawla P, Duhan JS. Fermentation: a boon for production of bioactive compounds by processing of food industries wastes (by-products). Molecules. 2018 Oct;23(10):2560. doi: 10.3390/molecules23102560 